\title{
Impact of cash conversion cycle for measuring the efficiency of cash management: A study on pharmaceutical sector
}

\author{
Somnath Das ${ }^{a^{*}}$ \\ ${ }^{a}$ Assistant Professor in commerce, Rabindra Mahavidyalaya, Champadanga, Hooghly, India

\section{A B S T R A C T}

\begin{tabular}{l}
\hline C H R O N I C L E \\
\hline Article history: \\
Received December 5, 2015 \\
Received in revised format \\
February 162016 \\
Accepted April 122016 \\
Available online \\
April 142016 \\
\hline Keywords: \\
Cash Conversion Cycle \\
Cash management \\
Receivable conversion period \\
Inventory conversion period \\
Payment deferral period \\
\end{tabular}

We know that Cash Conversion Cycle (CCC) is one of the measures of liquidity management. In this paper, we made an attempt to analyse the impact of CCC on the cash management. In this study we selected five companies from Pharmaceutical Sector, including, Alchemist, Lupin, Dr. Reddy's Laboratory, Cipla and Ranbaxy. In this study, we used the secondary data for analysis and retrieved from Capitaline database for ten years period from 2002 to 2011. Through cash conversion cycle we can easily determine the working capital requirement. Because, it considers the time gap between expenditure for the purchases of raw materials and collection from sales of finished goods prepared with such raw materials, CCC plays an important role in firm's short term assets and liabilities as well as success of the firm.

\section{Introduction}

Cash Conversion Cycle is the period between purchase of raw materials and collection from debtors (Das, 2015a). Through cash conversion cycle we can easily measure the efficiency of liquidity management (Das, 2015b). Nowadays it is frequently used as a parameter for measuring the quality of the liquidity management. Though cash conversion cycle we can easily assess the quality of liquidity management of the competitors. Liquidity management is nothing but the management of current assets and current liabilities (Bari, 1981). When the company pays off its current debts in time with the help of current assets, we can say that the liquidity management of the company is good (Coyle, 1999). Sometime, it is observed that companies collect funds from outside to pay off their short-term debt (Heston, et al., 1963; Horn, 1964; Bradley, 1974). But, it is not easy to collect funds from outside. It certainly imposes fixed burden to the company and holds a poor bottom line (Brandt, 1965). Therefore, efficient cash management system makes the company remain solvent. Cash Conversion Cycle (CCC) (Modigliani \& Miller, 1958; Moss\& Stine, 1993) is such a useful technique by which we can easily and quickly judge the liquidity of the company. It compares the time lag between cash payments for

* Corresponding author.

E-mail address: somnath211@gmail.com (S. Das) 
purchase of inventory and collection from customers (Chapman et al., 2006). Current ratio and quick ratio are useful indicators of liquidity (Moss \& Stine, 1993; Cohen\& Robbins, 1966) but static. Cash conversion cycle is a dynamic measure of continuous liquidity management where both balance sheet information and information regarding income statement are considered (Jose et al. 1996; Driscoll, 1983; Myers, 1984; Petersen \& Rajan, 1995; Ramamoorthy, 1978). Cash conversion cycle can be calculated with the help of following formula,

$\mathrm{CCC}=$ Days of Sales pending + Days of Sales in Inventory - Days of Payables pending.

Where, Days of Sales pending = Accounts Receivable / Sales / 365,

Days of Sales in inventory = inventory / Cost of goods Sold / 365 and

Days of payables pending $=$ Accounts Payables / Cost of goods sold $/ 365$.

$\mathrm{CCC}$ is either positive or negative. A positive Cash Conversion Cycle indicates a number of days a company is borrowing is less than the period awaiting payment from customer (Hawawini et al., 1986; Jensen, 1986). Conversely, negative CCC implies the number of days a company received cash from sales before it must pay its suppliers (Hutchison et al., 2007, p.42; Kieschnick et al., 2006). Therefore, the objective of every company is to minimize its CCC, if possible negative. Because shorter the CCC, signifies efficient cash management of the company.

\section{Literature Review}

Bergen (2006) undertook a study on 101 companies in Europe, the US and Canada in 2005. The study revealed four cash management models like decentralized liquidity and cash flow management, centralized liquidity and decentralized cash flow management, decentralized liquidity and centralized cash flow management and centralized liquidity and centralized cash flow management. It was also observed that decentralized organizations had the most to gain, as they were able to achieved considerable efficiencies through the introduction of a more centralized approach - perhaps through an SSC. Ortín-Ángel and Prior (2004) made a study on accounting turnover ratios and cash conversion cycle. The main objective of the study was to deduce the amount of days spent completing an operational process from turnover ratios. This study provided additional tools for financial statements analysis in order to get accurate result or working capital management. Deloof and Jegers (1996) undertook a study on working capital management. His study was based on cash conversion cycle. They used different measures relating to the time lag between expenditure for the purchase of raw materials and collection of sales of finished goods and argued that the longer the time lag, the larger the investment in working capital. Peel et al. (2000) made a study on credit management in small firm sectors. In this study they suggested that small firms were associated with larger quantum of current assets as compared to large firms. They also argued that small firms had less liquidity, more volatile cash flows and largely relied on short-term debt.

\section{Objectives of the Study}

The paper is prepared to make an in depth analysis of the impact of cash conversion cycle for measuring the efficiency of cash management. The study period is 2002-2011. Current ratio, quick ratio are the indicator of liquidity management. Higher current ratio as well as quick ratio signifies better liquidity of the organization. Cash conversion cycle is also a good indicator of liquidity. In this study we used the model of cash conversion cycle developed by Richards Laughlin (1980) and Giacomino and Mielke (1993).The objectives of the study are as follows.

(1) To calculate the CCC of the selected companies of Pharmaceutical sector with the help of receivable conversion period (RCP), inventory conversion period (ICP) and payment deferral period (PDP),

(2) To rank the companies on the basis of average cash conversion cycle and to rank the companies on the basis of consistency and finally to rank the companies on the basis of both average and consistency jointly, 
(3) To measure the degree of relationship between the cash conversion cycle and inventory turnover ratio (ITR), current ratio (CR), debtors turnover ratio (DTR), debtors more than six months and creditors turnover ratio (CTR) of each of the companies under study using Pearson simple correlation technique and to test such coefficient ' $t$ ' test has been used,

(4) To measure the degree of relationship between cash conversion cycle and inventory turnover ratio (ITR), current ratio (CR), debtors turnover ratio (DTR), Debtors more than six months and creditors turnover ratio (CTR) of each of the companies using Pearson's simple correlation technique and to test such coefficients ' $t$ ' test has been used,

(5) To analyse the joint impact of Return on Net Worth (RONW), size of the organization and cumulative profitability (Shareholders' fund) on the CCC of each of the selected companies with the help of multiple regression analysis and to test the significance of such regression coefficients, ' $t$ ' test has been applied,

(6) Finally to examine whether the findings of the study conform to the theoretical argument or not.

\subsection{Methodology of the study}

Five popular companies from Pharmaceutical sector have been selected for the study. The data of the selected companies for the period 2002 to 2011 used in this study have been taken from the secondary sources i.e. Capitaline Corporate Database of Capital Market Publishers (I) Ltd. Mumbai.Cash conversion cycle can be framed with the help of receivable conversion period, inventory conversion period and payment deferral period. Shorter cash conversion cycle means better liquidity position of the organization. Here, we established the relationship between CCC and debtors with more than six months, CCC and CR, CCC and inventory turnover ratio, CCC and debtors turnover ratio and CCC and creditors turnover ratio. Efficiency of the inventory management has been measured by inventory turnover ratio (ITR) which is the ratio between cost of goods sold and average stock. Higher ITR means lower CCC. So, ITR is negatively related with CCC. Debtors' turnover ratio (DTR) is the ratio of credit sales to average receivables. Higher DTR indicates lower CCC. Hence, DTR is also negatively related with CCC. Organization's ability to avail credit facility from suppliers has been measured by creditors' turnover ratio (CTR) which is the ratio of credit purchase to average payables. Low CTR means shorter CCC. Therefore, CCC is positively related with the CTR. Profitability, size of the organization and cumulative profitability can influence the cash conversion cycle of the organization. In this study profitability has been measured by return on net worth (RONW), size of the organization has been represented through the amount equal to the log value of total assets. Shareholders fund has been selected in this study as cumulative profitability which consists of equity share capital and reserve surpluses. The log value of shareholders' fund represents the cumulative profitability.

\section{Findings of the study}

Table 1 shows that in Pharmaceuticals Sector, the CCC of Alchemist Ltd. (Alchemist), is highest in 2002 (36.87 days) and lowest in the year 2004 (-88.47) on an average of 6.95 days. It is due to negative CCC in 2005 and 2004 for probably high period for deferral payments. Negative CCC may be the result of large deferral period for payments. So, Alchemist maintained a moderate liquidity position during the study period.

\section{Table 1}

Analysis of cash conversion cycle of selected companies of Pharmaceuticals sectors(in Days)

\begin{tabular}{cccccccccccc}
\hline COMPANIES & 2002 & 2003 & 2004 & 2005 & 2006 & 2007 & 2008 & 2009 & 2010 & 2011 & AVG \\
\hline ALCHEMIST & 36.87 & 29.01 & -88.47 & -49.48 & 4.49 & 21.65 & 35.96 & 33.49 & 20.44 & 25.55 \\
CIPLA & 101.96 & 132.02 & 161.99 & 144.55 & 150.37 & 178.95 & 169.16 & 164.17 & 183.63 & 157.12 & 154.39 \\
DR. REDDYS & 105.66 & 119.51 & 104 & 99.92 & 86.84 & 72.5 & 108.54 & 99.26 & 78.99 & 81.73 & \\
LUPIN & 134.41 & 146.40 & 113.41 & 97.91 & 91.42 & 107.42 & 124.52 & 125.32 & 114.70 & 126.44 & 118 \\
RANBAXY & 120.9 & 118.92 & 105.87 & 108.16 & 128.6 & 134 & 138 & 69.8 & 43.9 & 84.25 & 105.24 \\
\hline
\end{tabular}

Source: Compiled and computed from 'Capitaline Corporate Database' of Capital Market Publishers (I) Ltd., Mumbai. 
In case of Cipla it is found from Table 1 that the highest CCC is registered in the year 2010 (183.63 days) and lowest CCC is noticed in the year 2002 (101.96 days). On an average it is 154.39 days. It followed a mixed trend regarding its CCC. So from liquidity point of view the company fails to register its position.Table1 also depicts that the CCC of Dr. Reddys' Laboratories is highest in 2003 (119.51 days) and lowest in 2007 (72.5 days). On an average it is 95.7 days. It followed a mixed trend during the study period. Also the liquidity position of the company is not at all good. In case of Lupin Ltd. (Lupin), Table1 reveals that the CCC is highest in 2003 (146.4days) and lowest in 2006 (91.42 days). On an average it is 118 days. A mixed trend in CCC is noticed during the study period. Throughout the study period the liquidity position of the company is not sound enough as its CCC is larger than normal. Table 1 also shows that in the year 2006 (128.6days) Ranbaxy Laboratory Ltd. (Ranbaxy) registered the highest CCC and in the year 2010(43.9 days) it registered the lowest CCC. On an average it is 105.24 days. It also shows a mixed trend during the study period. So, on the basis of CCC, the liquidity position of the company is not at all sound enough. Therefore, among five companies of Pharmaceutical sector the short-term debt paying capacity of Alchemist is good as compared to other companies. From Fig.1 it is clear that except Alchemist all the Pharmaceuticals companies under study registered higher CCC.

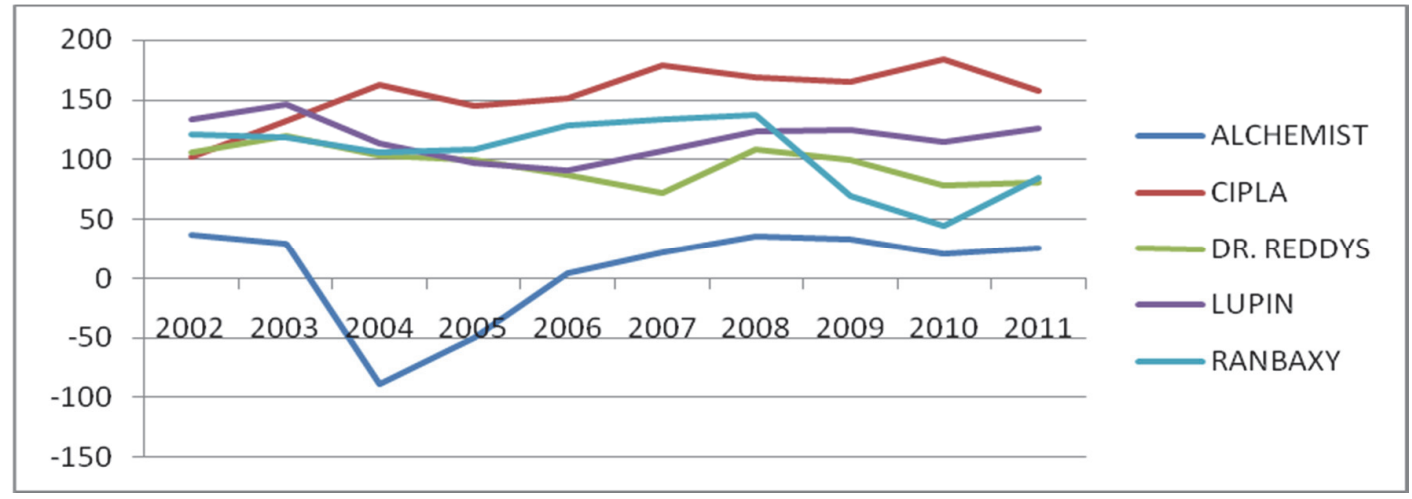

Fig. 1. Cash Conversion Cycle of Pharmaceutical Sector

Among the companies of pharmaceutical sector selected in this study the average CCC in Alchemist Ltd. is the lowest, followed by Dr. Reddys' Laboratory, Ranbaxy, Lupin and Cipla respectively in that order. Table 2 also reveals that in respect consistency of constructing CCC Lupin captured the top most position and followed byCipla, Dr. Reddys' Laboratory, Ranbaxy and Alchemist respectively. Considering both average and consistency aspects together Dr. Reddys's Laboratory and Lupin occupied the first rank jointly and it followed by Alchemist Ltd., Cipla and Ranbaxy in that order.

Table 2

Ranking on the basis of average and consistency of cash conversion cycle of the selected companies of Pharmaceuticals sector

\begin{tabular}{cccccccc}
\hline COMPANIES & AVG. & & $\begin{array}{c}\text { RANK } \\
\text { OF }\end{array}$ & $\begin{array}{c}\text { COEFFICIENT } \\
\text { OF } \\
\text { AVG. }\end{array}$ & $\begin{array}{c}\text { RANK } \\
\text { OF } \\
\text { VARIATION }\end{array}$ & $\begin{array}{c}\text { TOTAL } \\
\text { COEFFICIENT }\end{array}$ & $\begin{array}{c}\text { OVER } \\
\text { ALL } \\
\text { RANK }\end{array}$ \\
\hline ALCHEMIST & 6.95 & 42.1205 & 1 & 605.96 & 5 & 6 & 3 \\
CIPLA & 154 & 24.0358 & 5 & 15.568 & 2 & 7 & 4 \\
DR. & 95.7 & 14.987 & 2 & 15.661 & 3 & 5 & 1 \\
LUPIN & 118 & 16.6558 & 4 & 14.091 & 1 & 5 & 1 \\
RANBAXY & 105 & 30.4531 & 3 & 28.937 & 4 & 7 & 4 \\
\hline
\end{tabular}

Source: Compiled and computed from 'Capitaline Corporate Database' of Capital Market Publishers (I) Ltd., Mumbai. 
From Table 3 it has been found that in Pharmaceutical sector the correlation coefficients between CCC and ITR in Alchemist and Cipla are 0.601 and 0.207. But, the same in case of Dr. Reddys' Laboratories, Lupin and Ranbaxy are (-) 0.096, (-) 0.234 , and (-) 0.473 , which are statistically insignificant. The correlation coefficient between CCC and ITR in Alchemist and Cipla is positive but statistically not significant. It implies no such impact of ITR has been found on CCC.If we look at the Pharmaceutical sector, Table 3 exhibits that, the correlation coefficient between CCC and CR in Alchemist, Cipla, Dr. Reddey's Laboratory, Lupin and Ranbaxy are (-) $0.391,(-) 0.801,(-) 0.480$ and (-) 0.211 respectively. Out of which the correlation coefficient between CCC and CR in case of Dr. Reddys' Laboratory is statistically significant both at $5 \%$ and $1 \%$ level of significance. It indicates that the degree of negative association between CCC and CR in all the companies under Pharmaceuticals sector selected for this study. The liquidity condition regarding CCC is not sound enough. Table 3 exhibits that in Pharmaceutical sector the correlation coefficients between CCC and DTR inCipla, Dr. Reddys' Laboratory and Lupin are $0.940,0.524$ and 0.888 respectively. Out of which the correlation coefficient between CCC and DTR in case of Cipla and Lupin is statistically significant both at $5 \%$ and $1 \%$ level of significance. It implies sound debtors management system is adopted by these three companies which indirectly reduced the CCC. On the other hand, the same in case of Alchemist and Ranbaxy are (-) 0.106 and (-) 0.458 respectively. It implies the negative relationship between CCC and DTR.

In Pharmaceutical sector the correlation coefficient between CCC and debtors more than six months in Alchemist, Cipla and Lupin are (-) 0.546, (-) 0.632 and (-) 0.794 respectively. Out of which the same in case of Cipla and Lupin is statistically significant at $5 \%$ level. It implies negative association between CCC and debtors more than six months, which matched to the theoretical proposition. It is found from Table 3 that in Pharmaceutical sector the correlation coefficient between CCC and CTR in Dr. Reddy's Laboratories and Ranbaxy are (-) 0.635 and (-) 0.836 , such are statistically significant at $5 \%$ level. It indicated negative relationship between CCC and CTR. It is due to sound creditors' management by delaying payment which reduced the working capital requirement and indirectly minimizes CCC. But the correlation coefficient between CCC and CTR in Alchemist, Cipla and Lupin are 0.205, 0.704 and 0.145 respectively. Out of which the same in case of Cipla is statistically significant at $5 \%$ level. It indicates positive relationship between CCC and CTR which is not expected.

\section{Table 3}

Karl Pearson's simple correlation analysis between CCC and ITR, CR, DTR, Debt $>6$ months and CTR of the selected companies of Pharmaceuticals sector

\begin{tabular}{|c|c|c|c|c|c|c|c|c|c|c|}
\hline \multirow[t]{2}{*}{ COMPANIES } & \multicolumn{2}{|c|}{ CCC \& ITR } & \multicolumn{2}{|c|}{ CCC \& CR } & \multicolumn{2}{|c|}{ CCC \& DTR } & \multicolumn{2}{|c|}{$\begin{array}{c}\text { CCC \& DEBT }>6 \\
\text { MONTHS }\end{array}$} & \multicolumn{2}{|c|}{ CCC \& CTR } \\
\hline & (r) & 't' Value & (r) & 't' Value & (r) & 't' Value & (r) & 't' Value & (r) & 't' Value \\
\hline ALCHEMIST & 0.601 & 2.127 & -0.036 & -0.1 & -0.106 & -0.3 & -0.546 & -1.84 & 0.205 & 0.5924 \\
\hline CIPLA & 0.207 & 0.598 & -0.391 & -1.2 & $0.940 * *$ & 7.793 & $-0.632 *$ & -2.31 & $0.704 *$ & 2.8037 \\
\hline DR. REDDY & -0.096 & -0.27 & $-0.801 * *$ & -3.78 & 0.524 & 1.74 & 0.259 & 0.758 & $-0.635^{*}$ & -2.325 \\
\hline LUPIN & -0.234 & -0.68 & -0.480 & -1.55 & $0.888 * *$ & 5.462 & $-0.794 * *$ & -3.69 & 0.145 & 0.4145 \\
\hline RANBAXY & --0.473 & 1.518 & -0.211 & -0.61 & -0.458 & -1.46 & $0.655^{*}$ & 2.452 & $-0.836 * *$ & -4.309 \\
\hline
\end{tabular}

In Table4 an attempt has been made to assess the influence profitability, size of the organization and cumulative profitability on Cash Conversion Cycle. In this study, return on net-worth (RONW) has been taken as the measure of owners' profitability, log value of total assets has been taken as the measure of size of the organization and shareholder's fund has been taken as the measure of cumulative profitability. The linear regression equation has been fitted in this study is CCC $=b_{0}+b_{1}$ RONW + $b_{2}$ Size of Org. $+b_{3}$ Shareholders' fund, where $b_{0}$ is the value of intercept term (constant $)$ and $b_{1}, b_{2}$ and $\mathrm{b}_{3}$ are the slopes of the line i.e. the regression coefficient of CCC on RONW, size of org. and Shareholders' fund. This regression equation has been tested by ' $t$ ' test. 
Under Pharmaceutical sector, Table 4 depicts that for one unit increase in profitability the CCC of Alchemist is increased by only 0.086 units which is statistically not significant. Table 5 also shows that for one unit increase size of the organization and cumulative profitability the CCC of Alchemist is increased by 4.179 units and 15.988 units respectively and they are not statistically significant at $5 \%$ level. It indicates that profitability, Size of the organization and cumulative profitability, all are positively influenced the CCC of the organization. The coefficient of determination $\left(\mathrm{R}^{2}\right)$ makes it clear that only $7.5 \%$ of the variation of the company's CCC is accounted for by the variation in RONW, Size of Org and Shareholders' fund.

It is found from Table 4 that for one unit increase in profitability the CCC of Cipla reduced by only 0.011 unit which is statistically insignificant. Table 4 also reveals that for one unit increase in size of the organization, the CCC of Cipla stepped down by 3.371 units which is also statistically insignificant. Table- 5 shows that for one unit increase in cumulative profitability the CCC of the Cipla increased by 2.113 units which is statistically insignificant. So it indicates that profitability and size of the organization is negatively influenced the CCC of the company while cumulative profitability positively influenced the CCC of Cipla. The coefficient of determination $\left(\mathrm{R}^{2}\right)$ makes it clear that $59.1 \%$ of the variation of the company's CCC is accounted for by the variation in RONW, Size of Org and Shareholders' fund.

It has been observed from Table4 that for one unit increase in RONW the CCC of Dr. Reddy's Laboratories increased by only 0.026 units which is statistically not significant. It is also observed from table- 4 that for one unit increase in size of the organization the CCC of Dr. Reddys' Laboratory stepped up by 7.795 units which is not statistically significant. On the other hand table- 5 depicts that for one unit increase in cumulative profitability the CCC of Dr. Reddy's Laboratories is go down by 6.19 units which is statistically insignificant. It implies that RONW and size of the organization influenced the CCC of Dr. Reddys' Laboratory positively whereas the influence of Shareholders funds on CCC of the company is negative. The coefficient of determination $\left(\mathrm{R}^{2}\right)$ makes it clear that $60.9 \%$ of the variation of the company's CCC is accounted for by the variation in RONW, Size of Org and Shareholders' fund.

It has been depicted from Table 4 that for one unit increase in RONW the CCC of Lupin stepped up only by 0.015 units which is not significant whereas Table 4 shows that for one unit increase in the size of the organization the CCC of Lupin is decreased by 1.723 unit which is also not significant at $5 \%$ level. On the other hand, table shows that for one unit increase in cumulative profitability the CCC of Lupin go up by 1.021 units which is statistically insignificant. It implies that the profitability and cumulative profitability positively influence the CCC of Lupin whereas size of the organization is negatively influenced the CCC of Lupin. The coefficient of determination $\left(\mathrm{R}^{2}\right)$ makes it clear that only $8.5 \%$ of the variation of the company's CCC is accounted for by the variation in RONW, Size of Org and Shareholders' fund.

It is found from Table 4 that for one unit increase in profitability the CCC of Ranbaxy is go down by 0.031 units which is not statistically significant. The Table4 also portrays that for one unit increase in size of the organization the CCC of Ranbaxy go down by 3.311 unit which is statistically insignificant. The table also reveals that for one unit increase cumulative profitability the CCC of Ranbaxy is increased by 11.9 units which is also statistically insignificant. It indicates that RONW and size of the organization is negatively influenced the CCC of the company. It also indicates that only profitability influenced the CCC of the company positively. The coefficient of determination $\left(\mathrm{R}^{2}\right)$ makes it clear that $52 \%$ of the variation of the company's CCC is accounted for by the variation in RONW, Size of Org and Shareholders' fund. 
Table 4

Analysis of Multiple Regression of CCC on RONW, Size of Org. and shareholders' Fund of the Selected Companies of Pharmaceuticals Sector Regression Equation is CCC $=$ $\mathrm{a}_{0}+\mathrm{a}_{1}$ RONW $+\mathrm{a}_{2}$ Size of Org. $+\mathrm{a}_{3}$ Shareholders' Fund

\begin{tabular}{|c|c|c|c|c|c|}
\hline \multirow[t]{2}{*}{ COMPANIES } & \multicolumn{3}{|c|}{ PARTIAL REGRESSION COEFFICIENT } & \multirow{2}{*}{ CONSTANT } & \multirow[t]{2}{*}{$\mathrm{R}^{2} \mathrm{ED}$} \\
\hline & RONW & $\begin{array}{c}\text { SIZE OF THE } \\
\text { ORGANIZATION }\end{array}$ & $\begin{array}{c}\text { SHAREHOLDERS' } \\
\text { FUND }\end{array}$ & & \\
\hline ALCHEMIST & $\begin{array}{c}0.086 \\
(0.029)\end{array}$ & $\begin{array}{l}4.179 \\
(0.067)\end{array}$ & $\begin{array}{l}15.988 \\
(0.266)\end{array}$ & $\begin{array}{l}-25.122 \\
(-0.151)\end{array}$ & 0.075 \\
\hline CIPLA & $\begin{array}{c}-0.011 \\
(-0.342)\end{array}$ & $\begin{array}{c}-3.371 \\
(-0.825)\end{array}$ & $\begin{array}{l}2.113 \\
(0.507)\end{array}$ & $\begin{array}{l}7.119 \\
(2.781)\end{array}$ & 0.591 \\
\hline DR. REDDY & $\begin{array}{c}0.026 \\
(1.760)\end{array}$ & $\begin{array}{l}7.795 \\
(1.788)\end{array}$ & $\begin{array}{l}-6.190 \\
(-1.377)\end{array}$ & $\begin{array}{c}-2.563 \\
(-0.988)\end{array}$ & 0.609 \\
\hline LUPIN & $\begin{array}{c}0.015 \\
(0.439)\end{array}$ & $\begin{array}{l}-1.723 \\
(-0.504)\end{array}$ & $\begin{array}{c}1.021 \\
(0.403)\end{array}$ & $\begin{array}{c}5.273 \\
(1.244)\end{array}$ & 0.085 \\
\hline RANBAXY & $\begin{array}{c}-0.031 \\
(-0.654)\end{array}$ & $\begin{array}{l}-3.311 \\
(-0.804)\end{array}$ & $\begin{array}{l}11.900 \\
(1.760)\end{array}$ & $\begin{array}{l}-24.367 \\
(-1.922)\end{array}$ & 0.520 \\
\hline
\end{tabular}

Source: Compiled and computed from 'Capitaline Corporate Database' of Capital Market Publishers (I) Ltd., Mumbai.

Hence, under Pharmaceutical sector, only in case of Alchemist all the influencing factors like RONW, size of the organization and cumulative profitability influenced the CCC of the company positively. But, in other cases one or two such factors influenced the $\mathrm{CCC}$ of the company negatively.

\section{Conclusion}

Liquidity management is the management of current assets and current liabilities. The main purpose of liquidity management was to maintain current assets in such a way that it could meet the current liabilities timely. Sometime, external financing is used to pay off short-term debt. But, it is difficult to collect such external financing, particularly in case of small firms. External financing is very costly. So, the efficient liquidity management of the company helps its long-term prosperity and healthy bottom lines and more specifically to make the company remain solvent. Cash Conversion Cycle (CCC) is such a useful technique by which we can easily and quickly assess the liquidity of the firm. It invariably measures the time lag between cash payments for purchase of inventories and collection of receivables from customers. $\mathrm{CCC}$ is a dynamic measure of continuous liquidity management, which comprises both balance sheet and income statement data with time dimension. An individual firm's $\mathrm{CCC}$ is helpful but from industries stand point it is crucial for a company to evaluate its performance regarding CCC and assess opportunities for improvement because the length of CCC may differ from industry to industry. From the liquidity view point Alchemist is the best. From the point of view of average and consistency of maintain CCC, Dr. Reddy's Lab. and Lupin occupied the best place among the selected companies. But, the relationships between CCC and ITR, CCC and CR, CCC and DTR, CCC and Debtors more than six months and CCC and CTR in case of some companies are theoretically sound and in case of other companies are theoretically opposite. Out of which some factors positively and some factors negatively influenced the CCC of all the companies selected in this study.

\section{References}

Bari, R. R. (Ed.). (1981). Selected readings in cash management. Triveni Publications.

Bradley, J. F. (1974). Administrative financial management. New York.

Brandt, L. K. (1965). Business finance: a management approach. Prentice-Hall.

Bergen, J. (2006). Cash management best practice: Unlocking working capital. Retrieved from https://www.gtnews.com/articles/cash-management-best-practice-unlocking-working-capital/

Coyle, B. (1999). Cash flow control. Global Professional Publishing.

Chapman, C. S., Hopwood, A. G., \& Shields, M. D. (Eds.). (2006). Handbook of management accounting research (Vol. 1). Elsevier. 
Cohen, J. B., \& Robbins, S. M. (1966). The financial manager: basic aspects of financial Administration. Harper \& Row.

Das, S. (2015a). Impact of cash conversion cycle on cash holding-A study on FMCG sector. Accounting, 1(1), 1-16.

Das, S. (2015b). Management of corporate cash: A Study on retail sector.Accounting, 1(2), 51-68.

Deloof, M., \&Jegers, M. (1996). Trade credit, product quality, and intragroup trade: some European evidence. Financial Management, 25(3), 33-43.

Driscoll, M. C. (1983). Cash management: corporate strategies for profit. Wiley-Inderscience.

Giacomino, D. E., \&Mielke, D. E. (1993). Cash flows: Another approach to ratio analysis. Journal of Accountancy, 175(3), 55.

Hawawini, G., Viallet, C., \&Vora, A. (1986). Industry influence on corporate working capital decisions. Sloan Management Review (1986-1998), 27(4), 15.

Heston, A., Lindsay, R., \&Sametz, A. W. (1963). Financial Management: An Analytical Approach. The American Economic Review, 53(4), 799-801.

Horn, F. E. (1964). Managing cash. Journal of Accountancy (pre-1986),117(4), 56.

Hutchison, P. D., Farris II, M. T., \& Anders, S. B. (2007). Cash-to-cash analysis and management. The CPA Journal, 77(8), 42.

Jose, M. L., Lancaster, C., \& Stevens, J. L. (1996). Corporate returns and cash conversion cycles. Journal of Economics and finance, 20(1), 33-46.

Jensen, M. C. (1986). Agency cost of free cash flow, corporate finance, and takeovers. Corporate Finance, and Takeovers. American Economic Review,76(2), 323-329.

Kieschnick, R., Laplante, M., \&Moussawi, R. (2006). Corporate working capital management: determinants and consequences. International Journal of Managerial Finance, 3(2), 164-177.

Modigliani, F., \& Miller, M. H. (1958). The cost of capital, corporation finance and the theory of investment. The American Economic Review, 48(3), 261-297.

Moss, J. D., \& Stine, B. (1993). Cash conversion cycle and firm size: a study of retail firms. Managerial Finance, 19(8), 25-34.

Myers, S. C. (1984). The capital structure puzzle. The journal of finance,39(3), 574-592.

National Association of Accountants (1961). Cash Flow Analysis for managerial Control, N.A.A. Research Report no. 38, New York.

National Council of Applied Economic Research (1966).Structure of working Capital, New Delhi.

Ortín-Ángel, P., \& Prior, D. (2004). Accounting turnover ratios and cash conversion cycle. Problems and Perspectives in Management, 1, 189-205.

Peel, M. J., Wilson, N., \&Howorth, C. (2000). Late payment and credit management in the small firm sector: some empirical evidence. International Small Business Journal, 18(2), 17-37.

Petersen, M. A., \&Rajan, R. G. (1995). The effect of credit market competition on lending relationships. The Quarterly Journal of Economics, 110(2), 407-443.

Ramamoorthy, V.E. (1978). Working Capital Management.Institute for financial management, and research, Madras. 